\title{
The Effect of Interactive Reading Aloud Activities on the Reader Self-perception of Primary School Students ${ }^{i}$
}

\author{
Sümeyra Ceyhan", Mustafa Yıldız \\ Faculty of Education, Gazi University, Turkey
}

Copyright $\subseteq 2019$ by authors, all rights reserved. Authors agree that this article remains permanently open access under the terms of the Creative Commons Attribution License 4.0 International License

\begin{abstract}
The objective of this study is to examine the effect of interactive reading aloud activities on the reader self-perception levels. The study is an experimental study, which aims for revealing and describing the existing situation. The study group consists of 82 students receiving education at the second grade in a public school affiliated to the MNE (the Ministry of National Education) and located in Çankaya district of Ankara province. With 42 students included in the experimental group, "Interactive Reading Aloud" activities covering a total period of 33 course hours have been carried out for 11 weeks; as for 40 students in the control group, they have not attended these activities. In the study, "Reader Self-perception Scale" developed by Chapman and Tunmer [9] and adapted to Turkish language by Yildiz and Bulut [35] has been used as data collection tool. The obtained data have been analyzed by the statistical package SPSS. In consequence of analyses, it has been determined that the reader self-perception levels of the students having attended the interactive reading aloud activities are significantly high.
\end{abstract}

\section{Keywords Reading, Reader Self-perception,} Interactive Reading Aloud

\section{Introduction}

Reading is the process of meaning making which prior knowledge is used in, and it is based on the effective communication between the writer and reader and is realized in line with an appropriate method and aim in a regular environment [1]. In the process of making meaning, the reader's interest, motivation, purpose of reading, skills and world knowledge have an influence. Reading, in brief, can be defined as an active process throughout which the individual generates new meanings by integrating his prior knowledge into the information introduced in the text [15].

It is seen that several affective properties have effect on the students' reading skill when the body of literature is reviewed. Some of these affective properties are self-efficacy [30], attitude [25], motivation [4] and self-perceiving [17]. One of the affective properties, which are thought to have an influence on reading, is also self-perception [35]. Self is the manner of individual for perceiving the beliefs and thoughts for his own personality, and also his self [3]. Reader self-perception corresponds to the children's some belief, observation and attitudes towards their own reading acts and reading activities, as individuals learning [30]. According to Chapman and Tunmer [10], reading-self-concept is a notion consisting of the perception of competence for reading, perception of disability for reading and attitude towards reading.

Reading skill is one of the most considerable factors, which contribute to the developments of students both in the academic and social areas. In order to enhance and develop the primary school students' reading skills, a great variety of reading studies and activities have been carried out. And as well, one of these is the activities for "Interactive Reading Aloud" (IRA) [34]. The IRA process involves the teacher's actualizing reading aloud practices for the students, thinking aloud to strengthen the comprehension and be a model over the course of these readings, and while listening to their teachers, the students' discussing about the book with their peers under their teacher's supervision, guessing at, answering the questions directed and vocabulary teaching.

During IRA activities, contrary to only listening, students interact with their teacher and the text being read at the very moment and therefore, participate in the class actively; and meanwhile, the teacher asks questions, answers the questions directed, establishes correlations, gives explanations for the unknown words and summarizes. After each reading act, students give answers to several reading comprehension questions. These activities allow students to be interaction with the book that has been read, their teacher and peers. Students can ask questions, correlate, and discuss about the characters [16].

Interactive reading aloud (IRA) process stands for the 
activities realized within the scope of student-teacher interaction that includes teacher's reading aloud to students, thinking aloud to strengthen the comprehension during these readings and while listening to their teacher, students' making discussions about the book with their classmates, guessing at and answering the questions directed to them under the supervision of their teacher, and teaching vocabulary.

As for the child's reader self-perception, it is a concept required to be evaluated especially by considering the social condition in which the child is together with his teacher and peers [30]. According to Johnson and Giorgis [19], the discussions made after aloud readings performed by the parents, teachers and students enable their students' comprehension to be well-developed and them to be an independent reader.

When books are read aloud to students, both teachers and students delight in reading book [19]. Furthermore, Albright and Ariail [2] stated that the teacher's reading a book aloud to his students knowing how to read but not wanting to read could motivate them to be an independent reader. Similarly, Morgan [26] asserted that teachers have been able to make their students be motivated to read independently when they enable the books to be pleasant and read aloud to their students. Duncan [12] put forth that teachers perform a literary practice while reading aloud in the class and a story enthusiasm may be a way for the readers who are not willing to buy a book and cannot comprehend what they read on their own to like the book. When the students are in cooperation with their classmates, think that they will be successful, become a competent reader and have their own chances for choosing the book they will read, they also become more interested in reading [33].

It has been seen in several studies that a positive correlation exists between the increasing independent reading motivations and increasing general academic achievements of the students to whom reading aloud is performed by their teachers and parents [12, 23, 33, 34]. When the literature is reviewed, several studies within the scopes of which the effect of IRA activities on cognitive and affective properties related to reading skill is analyzed have been encountered with. According to Muller [28], performing IRA activities to the students is the most effective way to enhance their motivation for reading. In another study, Spencer [32] pointed out that reading aloud to students has developed reading comprehension, improved fluent reading and enriched vocabulary. Morrison and Wlodarczyk [27] determined the benefits of reading aloud as the improvement of linguistic skills, improvement of listening and speaking skills, gaining vocabulary, development of comprehension and fluency, and the increase of motivation for independent reading. In the studies they carried out, Trelease [34] and Kindle [22] concluded that the scores for their positive attitude towards reading and success increased in consequence of practising IRA activities to the students. When considering the literature, it has been realized that IRA activities have an effect on the affective and cognitive processes of reading skill. However, in Turkey, any study addressing to this close relation has not been observed. This study conducted has a place and importance with the thought that it can meet the deficit in the literature. In line with this general purpose, answer will be sought to the following questions.

- Do the levels of reader self-perception of the classes in which IRA activities are and are not carried out vary?

- Do the levels of perception of competence for reading vary by the classes in which IRA activities are and are not carried out?

- Do the levels of perception of disability for reading vary by the classes in which IRA activities are and are not carried out?

- Do the levels of attitude towards reading vary by the classes in which IRA activities are and are not carried out?

\section{Method}

The study was carried out by weak experimental design included in quantitative research models. Within the scope of the study, as only posttest scores and experimental and control groups are involved, static group is the comparative weak experimental design. In this design, one of the groups is dealt with as experimental group and the other as control, without random assignment or matching of the subjects to the groups [7].

\subsection{Study Group}

The study group consists of 82 students attending the second grade in a public school affiliated to the MNE, in Çankaya district of Ankara province, in the second term of the academic year 2017-2018. Two experimental and two control groups are included in the study. Control 1 (20) and control 2 (20) classes are the control groups; in other words, the classes in which no additional practice is carried out. Experimental 1 (20) and experimental 2 (22) classes are the experimental groups. In those classes, IRA activities were performed during 11 weeks. In the class Experimental 1, the practice was carried out by the classroom teacher, but by the researcher in the class Experimental 2. Only the practitioners changed their places while the same plan and activities were included.

\subsection{Data Collection Tools}

In the study, "Reader Self-Perception Scale" developed by Chapman and Tunmer [9] and adapted to Turkish language by Yıldiz and Bulut [35] was used. The scale is in the structure of 3 factors (competence, attitude, disability) each of which consists of 10 items. The 
Cronbach's Alpha reliability coefficient of the scale in general was estimated as $\alpha=.86$

\subsection{Process of Practising}

Prior to starting the practice, all necessary permissions were obtained from the MNE and relevant interviews were made with the school administration. After the classes in which activities would be carried out were agreed, the classroom teachers were informed about the activities to be realized, and the details of IRA activities were explained to the teacher who would perform the practice in person.

The whole process of practising was actualized in the following way:

11 illustrated children's books which would be included in IRA activities were chosen by three specialists in that area out of 50 illustrated children's books analyzed by using a textbook evaluation form enabling the book having been developed for that study to be considered and evaluated in terms of its suitability to the development level of students, its specific features such as physical properties and subject. For each book, certain plans appropriate for the IRA activities were prepared. IRA activities were put into practice in the way that it would be carried out as one class hour per three days a week, namely 33 course hours during 11 weeks in total.

\subsection{Data Collection Process}

At the end of practising, to the experimental and control classes, the items in "Reader Self-Perception Scale" was read aloud to the whole class, by taking the class level into consideration, the students were asked to follow the scale items read and to mark the choice which they would find appropriate.

\subsection{Analysis of Data}

With the objective to analyze whether the students' scores obtained from the reader self-perception and its sub-dimensions within the scope of the study have revealed out statistically significant difference as to the experimental and control groups, or not, ANOVA analysis in case that the range of scores was normal in all classes, and in the contrary case, Kruskal Wallis Test was used. In order to examine whether or not the range of scores was normal, kurtosis and skewness values were taken as criteria. Providing that kurtosis and skewness value was between -1 and +1 , the range of score was regarded normal, but if not so, it was regarded not normal. Data obtained in the study was analyzed by the use of statistical package program.

\section{Findings}

Descriptive statistics for the reader self-perception scores of the students included in the scope of this study are given below.

As is seen from Table 1, the averages of reader self-perception score of the students included in both experimental and control group are above the mid-level. The class including the student with the lowest reader self-perception score is $2 \mathrm{D}$, while the one including the student who has the highest reader self-perception score is $2 \mathrm{C}$. When Table is analyzed, it is seen that the skewness and kurtosis values of the range of scores for the reader self-perception of students in $2 \mathrm{D}$ and $2 \mathrm{E}$ classes are between -1 and +1 ; and therefore, the range of reader self-perception scores in these groups is normal. However, since the skewness and kurtosis values of the range of scores for the reader self-perception of students in $2 \mathrm{~B}$ and $2 \mathrm{C}$ classes are not between -1 and +1 , the range of reader self-perception scores in these groups is not normal. As the range of scores for the reader self-perception that belongs to each class is not normal, Kruskal Wallis test has been applied with the purpose of determining whether reader self-perception scores vary by the presence of the students in experimental or control groups, or not. Obtained results are included in Table 2.

Table 1. Descriptive statistics for the reader self-perception scores by classes.

\begin{tabular}{cccccccc}
\hline Class & $\mathbf{N}$ & $\overline{\boldsymbol{X}}$ & $\begin{array}{c}\text { Standard } \\
\text { Deviation }\end{array}$ & Minimum & Maximum & Skewness & Kurtosis \\
\hline 2B (Control) & 20 & 112,55 & 8,65 & 97 & 135 & 0,44 & 1,29 \\
\hline 2C (Experimental) & 20 & 124,10 & 9,79 & 113 & 149 & 1,47 & 1,51 \\
\hline 2D (Control) & 20 & 110,50 & 11,03 & 94 & 136 & 0,70 & 0,14 \\
\hline 2E (Experimental) & 22 & 124,59 & 7,19 & 108 & 137 & $-0,80$ & 0,78 \\
\hline
\end{tabular}

Table 2. Results of Kruskal Wallis test for the analysis of reader self-perception scores as to the experimental and control groups.

\begin{tabular}{|c|c|c|c|c|c|c|}
\hline Class & $\mathbf{N}$ & Mean Rank & $\chi^{2}$ & sd & $\mathbf{p}$ & Difference \\
\hline 2B (Control) & 20 & 28,05 & \multirow{4}{*}{30,70} & \multirow{4}{*}{3} & \multirow{4}{*}{$0,00^{*}$} & \multirow{4}{*}{$\begin{array}{l}2 \mathrm{C}>2 \mathrm{~B}, 2 \mathrm{C}>2 \mathrm{D} \\
2 \mathrm{E}>2 \mathrm{~B}, 2 \mathrm{E}>2 \mathrm{D}\end{array}$} \\
\hline 2C (Experimental) & 20 & 52,90 & & & & \\
\hline 2D (Control) & 20 & 25,40 & & & & \\
\hline 2E (Experimental) & 22 & 58,00 & & & & \\
\hline
\end{tabular}


As is seen in Table 2, the reader self-perception scores of the students participating in the study significantly vary by the classes, which they are in $\left(X^{2}=30,70 ; p=0,00<\right.$ $0,05)$. When paired comparisons obtained in consequence of nonparametric post hoc tests applied to determine from which classes that statistically significant difference resulted were analyzed, it was detected that the reader self-perception scores of the students in $2 \mathrm{C}$ and $2 \mathrm{E}$, namely experimental groups, were higher that the reader self-perception scores of the students in 2B and 2D classes, i.e. the control group. As based on this result, it can be said that performing interactive reading aloud activities is one of the factors contributing to the development of students' reader self-perception in a positive way.

Descriptive statistics for the scores of the competence, disability and attitude sub-dimensions of the reader self-perception scale obtained by the students included within the scope of the study are given in Table 3 .

As is seen from Table 3, the averages of scores for the competence, disability and attitude sub-dimensions of the scale obtained by the students included in both experimental and control group are above the mid-level. While the class including the student with the lowest score of competence is $2 \mathrm{D}$, the classes including the student with the highest score of competence are $2 \mathrm{C}$ and $2 \mathrm{E}$. Similarly, $2 \mathrm{D}$ is the class in which the student having the lowest score of attitude is, and $2 \mathrm{C}$ and $2 \mathrm{E}$ are the classes including the student with the highest score of attitude. In terms of the scores for the disability sub-dimension, the classes $2 \mathrm{C}$ and $2 \mathrm{E}$ are the ones which the student with the lowest score of disability is in, while the class $2 \mathrm{C}$ includes the student who has the highest score of disability. Considering the values of skewness and kurtosis that are presented in Table 3, since the skewness and kurtosis values pertaining to the range of scores for the attitude sub-dimension are between -1 and +1 in all classes, the range of scores for the attitude sub-dimension in all the classes is normal. However, this case is not acceptable for the range of scores obtained from the competence and disability sub-dimensions. As the range of scores for the attitude sub-dimension per each class is normal, ANOVA analysis has been applied in order to examine whether students' scores for attitude vary by their presence in the experimental or control groups, or not. On the other hand, Kruskal Wallis test has been carried out with the aim of examining whether or not the scores for attitude vary according to the presence of the students in the experimental or control groups, since the range of scores for the competence and disability sub-dimensions per each class is not normal. Obtained results are included in Table 4.

When the results of ANOVA analysis and Kruskal Wallis test applied as related to the scores obtained from the sub-dimensions pertaining to the reader self-perception scale presented in Table 4 were analyzed, it was detected that the scores obtained by the second graders in the attitude, competence and disability sub-dimensions varied as to be considered statistically significant by the students' classes $\left(F_{\text {Attitude }}(3,81)=22,37, \quad X_{\text {Competence }}^{2}(\mathrm{sd}=3\right.$, $\left.\mathrm{N}=82)=44,72, X_{\text {Disability }}^{2}(\mathrm{sd}=3, \mathrm{~N}=82)=11,82\right)$. As a result of the post hoc test applied in order to determine the basis of variance, when considering the students' averages for the attitude sub-dimension, it has been realized that the statistically significant difference is between $2 \mathrm{C}$ and $2 \mathrm{~B}$ and $2 \mathrm{C}$ and $2 \mathrm{D}$ in favour of the class $2 \mathrm{C}$, and between $2 \mathrm{E}$ and $2 \mathrm{~B}$ and $2 \mathrm{E}$ and $2 \mathrm{D}$ as to be in favour of the class $2 \mathrm{E}$. As based on the result of nonparametric post hoc tests, it has been concluded that the statistically significant difference existed in the scores for the competence sub-dimension is between $2 \mathrm{C}$ and $2 \mathrm{~B}$ and $2 \mathrm{C}$ and $2 \mathrm{D}$ in favour of the class $2 \mathrm{C}$, and between $2 \mathrm{E}$ and $2 \mathrm{~B}$ and $2 \mathrm{E}$ and $2 \mathrm{D}$ as to be in favour of the class $2 \mathrm{E}$. According to another result, it has been found out that the statistically significant difference existed in the scores for the disability sub-dimension is between $2 \mathrm{~B}$ and $2 \mathrm{C}$ and $2 \mathrm{~B}$ and $2 \mathrm{E}$ in favour of the class $2 \mathrm{~B}$, and between $2 \mathrm{D}$ and $2 \mathrm{C}$ and $2 \mathrm{D}$ and $2 \mathrm{E}$ as to be in favour of the class $2 \mathrm{D}$. In the light of the results attained, the scores for the attitude and competence sub-dimensions by the students in the experimental groups are higher than these of the students included in the control group; however, for the scores obtained from the disability sub-dimension, the exact opposite situation exists. According to the results reached at, it can be stated that carrying out interactive reading aloud activities is one of the factors being able to decrease the scores for disability by increasing the scores for attitude and competence of the students. 
Table 3. Descriptive statistics for the scores of competence, disability and attitude sub-dimensions of the scale by the classes.

\begin{tabular}{|c|c|c|c|c|c|c|c|c|}
\hline & Class & $\mathbf{N}$ & $\bar{X}$ & Std. D. & Minimum & Maximum & Skewness & Kurtosis \\
\hline \multirow{4}{*}{ Competence } & 2B (Control) & 20 & 37,45 & 5,06 & 27 & 46 & $-0,60$ & 0,29 \\
\hline & $2 \mathrm{C}$ (Experimental) & 20 & 44,90 & 3,55 & 40 & 50 & 0,08 & $-1,42$ \\
\hline & 2D (Control) & 20 & 34,90 & 6,57 & 20 & 47 & $-0,54$ & 0,44 \\
\hline & 2E (Experimental) & 22 & 45,50 & 3,33 & 40 & 50 & 0,10 & $-1,26$ \\
\hline \multirow{4}{*}{ Disability } & 2B (Control) & 20 & 37,30 & 3,61 & 32 & 44 & 0,04 & $-1,13$ \\
\hline & $2 \mathrm{C}$ (Experimental) & 20 & 32,70 & 7,16 & 23 & 49 & 0,55 & $-0,20$ \\
\hline & 2D (Control) & 20 & 36,70 & 6,95 & 24 & 48 & $-0,27$ & $-1,01$ \\
\hline & 2E (Experimental) & 22 & 32,36 & 4,77 & 23 & 38 & $-0,64$ & $-0,94$ \\
\hline \multirow{4}{*}{ Attitude } & 2B (Control) & 20 & 38,15 & 5,32 & 30 & 49 & 0,46 & $-0,35$ \\
\hline & 2C (Experimental) & 20 & 46,40 & 3,33 & 39 & 50 & $-0,76$ & $-0,41$ \\
\hline & 2D (Control) & 20 & 38,90 & 5,49 & 29 & 47 & $-0,35$ & $-0,78$ \\
\hline & 2E (Experimental) & 22 & 46,55 & 3,01 & 40 & 50 & $-0,49$ & $-0,81$ \\
\hline
\end{tabular}

Table 4. Results of ANOVA and Kruskal Wallis test for the analysis of the scores for competence, disability and attitude by the experimental and control groups

\begin{tabular}{|c|c|c|c|c|c|c|c|}
\hline ANOVA & Basis of Variance & $\begin{array}{c}\text { Sum of } \\
\text { Squares }\end{array}$ & $\begin{array}{l}\text { Mean of } \\
\text { Squares }\end{array}$ & sd & $\mathbf{F}$ & $\mathbf{p}$ & Difference \\
\hline \multirow{3}{*}{ Attitude } & Inter-groups & 1301,12 & 433,71 & 3 & \multirow{3}{*}{22,37} & \multirow{3}{*}{$0,00^{*}$} & $2 \mathrm{C}>2 \mathrm{~B}$ \\
\hline & Intra-groups & 1512,61 & 19,39 & 78 & & & $\begin{array}{l}2 \mathrm{C}>2 \mathrm{D} \\
2 \mathrm{~F}>2 \mathrm{~B}\end{array}$ \\
\hline & Total & 2813,72 & & 81 & & & $2 \mathrm{E}>2 \mathrm{D}$ \\
\hline Kruskal-Wallis & Group & $\mathbf{N}$ & Mean Rank & sd & $\chi^{2}$ & $\mathbf{p}$ & Difference \\
\hline \multirow{4}{*}{ Competence } & 2B (Control) & 20 & 26,53 & \multirow{4}{*}{3} & \multirow{4}{*}{44,72} & \multirow{4}{*}{$0,00^{*}$} & \multirow{4}{*}{$\begin{array}{l}2 \mathrm{C}>2 \mathrm{~B} \\
2 \mathrm{C}>2 \mathrm{D} \\
2 \mathrm{E}>2 \mathrm{~B} \\
2 \mathrm{E}>2 \mathrm{D}\end{array}$} \\
\hline & 2C (Experimental) & 20 & 56,88 & & & & \\
\hline & 2D (Control) & 20 & 20,80 & & & & \\
\hline & $2 \mathrm{E}$ (Experimental) & 22 & 59,95 & & & & \\
\hline \multirow{4}{*}{ Disability } & 2B (Control) & 20 & 52,13 & \multirow{4}{*}{3} & \multirow{4}{*}{11,82} & \multirow{4}{*}{$0,00^{*}$} & \multirow{4}{*}{$\begin{array}{l}2 \mathrm{C}<2 \mathrm{~B} \\
2 \mathrm{C}<2 \mathrm{D} \\
2 \mathrm{E}<2 \mathrm{~B} \\
2 \mathrm{E}<2 \mathrm{D}\end{array}$} \\
\hline & 2C (Experimental) & 20 & 33,25 & & & & \\
\hline & 2D (Control) & 20 & 49,25 & & & & \\
\hline & 2E (Experimental) & 22 & 32,30 & & & & \\
\hline
\end{tabular}

\section{Conclusions and Discussion}

In this study, the effect of interactive reading aloud activities on the reader self-perception of second graders at primary school has been analyzed. For this purpose, the reader self-perception scores of the students receiving education in two each classes which interactive reading aloud activities are and are not carried out have been compared. In accordance with the findings obtained from the study, it has been detected that the reader self-perception scores and the scores for attitude towards reading and competence, which are from the sub-dimensions of the reader self-perception scale, of the students in the classes in which the interactive reading aloud activities are practised by the researcher and teacher are higher when compared to the classes which interactive reading aloud activities are not performed in. Yet, it has been concluded that a case exactly opposite exists in terms of the students' perception of disability for reading that is the other sub-dimension; in other words, the scores for the perception of disability are lower in the classes, in which IRA activities are carried out, in comparison to the classes, in which IRA activities are not carried out.

In the researches carried out, Kindle [22], Laminack \& Wadsworth [24], Morgan [26], Tompkins [33], Trelease [34] concluded that IRA activities could increase the achievement scores in reading, and also that they could improve the students' comprehension, fluency and vocabulary was found by Johnson \& Giorgis [19], Laminack \& Wadsworth [24], Tompkins [33]. Students' attitudes towards reading are also affected by their self-perception; and therefore, it can be considered that students who feel themselves academically competent can be more eager to read, tend to read more by themselves and so, they can be more successful at reading [35]. Accordingly, the fact that the levels of self-perception 
towards reading are higher in the classes which IRA activities are practised in than the ones in which these activities are not carried out is compatible with the body of literature. Moreover, another explanatory sign of the positive effect of IRA activities on the self-perception towards reading is the positive contributions of IRA activities on the motivation for reading. In fact, according to Bulut and Yildiz [35], one of the key aspects in the conceptualization of the self-perception concept of reading is the motivation for reading. Also, Muller [28] pointed out that IRA activities are solely one of the most effective ways to enhance motivation for reading. Thus, we can also state that IRA activities have a positive effect indirectly by based upon motivation for reading on the self-perception towards reading.

Reading aloud has been one of the earliest practices, which enables the achievement at the level of primary school, in the history of education [34]. IRA activities ensure increase in positive attitude towards reading and motivation, besides its improving the comprehension, analysis, vocabulary, reading fluency and listening skills [2, $33,34]$. The researches within the body of literature demonstrate that reading aloud to students increases their positive attitudes towards reading and their grades for achievement $[22,24,26,33,34]$. In a similar way, that reading aloud activities that it is necessary for students to be individuals performed by the parents out of the classroom environment have also effect on the students' attitudes towards reading in a positive manner is included in the studies available in the literature [23]. Braun [6] stated that their students' attitudes would be affected positively when the teachers realize reading aloud practices; Eagley and Chaiken [13] indicated that motivation increases on condition that the attitude is positive. Reading aloud is a significant means of motivation in enabling students to become an independent reader [27]. By the time teachers make their students practise text studies, students not only become an independent reader, but also learn what the learning is [8]. Tompkins [33] revealed that motivation is internal and all of us have an innate curiosity that impels us to understand something, and also indicated who have self-confidence, believe that they will be successful, and take pleasure in reading. Hurst et al. [18] stated that students enjoy reading aloud in the classroom environment and gain self-confidence when teachers provide students with the opportunity of reading aloud to their classmates. It has been proved many times that reading aloud to primary school students effect their perception towards reading in a positive manner, and also encourage them to perform independent readings $[33,34]$. In the light of such information, we are able to express that IRA activities will positively affect the students' attitudes towards reading, their perception for competence and for disability.

\section{Suggestions}

In order that the reader self-perception of primary school students can be improved in a positive manner, teachers may include IRA activities in their classes. For teachers to be able to realize IRA activities in a more systematic and effective way, theoretical and applied courses involving IRA practices may be included in the curriculum in the relevant departments of faculty of education. The MNE may add IRA activities into the primary school instructional programme, within the scope of activities relevant to reading instruction at primary school education. Even if a planned and systematic IRA process is not available, parents can read books to their children at home, as of early ages. The effect of IRA activities on Reader Self-Perception can be analyzed more comprehensively by an experimental study within the scope of which pretest process is implemented. Also, the relations of IRA activities with the other cognitive and affective features may be dealt in other researches.

\section{REFERENCES}

[1] Akyol, H. (2011). Türkçe İlk Okuma Yazma Öğretimi. Pegem Yayıncilık, Ankara.

[2] Albright, L. \& Ariail, M. (2005). Tapping the potential of teacher read-alouds in middle schools. Journal of Adolescent \& Adult Literacy, 48(7), 582-591.

[3] Aslan, E. (1992). Benlik kavramı ve bireyin yaşamındaki etkileri. Marmara Üniversitesi, Atatürk Eğitim Fakültesi, Eğitim Bilimleri Dergisi (4), 7-14.

[4] Baker, L., \& Wigfield, A. (1999). Dimensions of children's motivation for reading and their relations to reading activity and reading achievement. Reading research quarterly, 34(4), 452-477.

[5] Braun, P. (2010). Taking the time to read aloud. Science Scope, 34(2), 45.

[6] Büyüköztürk, Ş., Çakmak, K. E., Karadeniz, Ş. \& Demirel, F. (2016). Bilimsel araştırma yöntemleri. Ankara: Pegem A.

[7] Boyd, M. \& Devennie, M. (2009). Student voices and teacher voices: Selecting chapter book read-aloud. Childhood Education, 85(3), 148-153.

[8] Chapman, J.W., \& Tunmer, W.E. (1995). Development of young children's reading self-concepts: An examination of emerging subcomponents and their relationship with reading achievement. Journal of Educational Psychology, 87, 154-167.

[9] Chapman, J.W., \& Tunmer, W.E. (1997). A longitudinal study of beginning reading achievement and reading self-concept. British Journal of Educational Psychology, 67, 279-291. 
[10] Duncan, S. P. (2010). Instilling a lifelong love of reading. Kappa Delta Pi Record, 46(2), 90-93.

[11] Eagly, A. H., \& Chaiken, S. (1993). The psychology of attitudes. Harcourt Brace Jovanovich College Publishers.

[12] Güneş, F. (2014). Türkçe öğretimi yaklaşımlar ve modeller. Pegem: Ankara.

[13] Hazzard, K. (2016). The Effects of read alouds on student comprehension.

[14] Henk, W. A., Marinak, B. A., \& Melnick, S. (2012). Measuring the reader self-perceptions of adolescents: Introducing the rsps2. Journal of Adolescent \& Adult Literacy, 56(4), 311-320.

[15] Hurst, B., Scales, K., Frecks, E., Lewis, K. (2011). Sign up for reading: Students read aloud to the class. The Reading Teacher, 64(6), 439-443.

[16] Johnson, N. J., \& Giorgis, C. (2003). Children's Books: Literature in the Reading Curriculum. The Reading Teacher, 56(7), 704-712.

[17] Kindle, K. (2009). Vocabulary development during read-alouds: Primary practices. The Reading Teacher, 63(3), 202-211.

[18] Kotaman, H. (2013). Impacts of dialogical storybook reading on young children's reading attitudes and vocabulary development. Reading Improvement, 50(4), 199-204.

[19] Laminack, L. L., \& Wadsworth, R. M. (2006). Reading aloud across the curriculum: How to build bridges in language arts, math, science, and social studies. Porthsmouth, NH: Heinemann.

[20] McKenna, M.C., Kear, D.J., \& Ellsworth, R.A. (1995). Children's attitudes toward reading: A national survey. Reading Research Quarterly, 30, 934-955.

[21] Morgan, H. (2009). Using read-aloud with culturally sensitive children's books: A strategy that can lead to tolerance and improved reading skills. Reading Improvement, 46(1), 3-8.

[22] Morrison, V., \& Wlodarczyk, L. (2009). Revisiting read aloud: Instructional strategies that encourage students' engagement with texts. The Reading Teacher, 63(2), 110-118.

[23] Muller, P. (2005). Teen read Week meets read aloud to a child week in Virginia. Young adult library services Fall 2005 pg. $23,24$.

[24] Pretzlik, U., \& Chan, L. (2004). Children's self-perception as readers. In Handbook of children's literacy (pp. 119-146). Springer, Dordrecht.

[25] Solheim, O. J. (2011). The impact of reading self-efficacy and task value on reading comprehension scores in different item formats. Reading Psychology, 32(1), 1-27.

[26] Spencer, R. R. (2011). Reading Aloud and Student Achievement. (Doctoral dissertation), Education Faculty of Lindenwood University.

[27] Tompkins, G., Campbell, R., Green, D., \& Smith, C. (2016). Literacy for the 21st century. Pearson Australia.

[28] Trelease, J. (2013). The Read-Aloud Handbook. New York,
NY: Pengin Group.

[29] Yıldız, M. ve Bulut, A. (2016). Okur Benlik Algısı Ölçeği: Geçerlik ve Güvenirlik Çalışması, International Journal Of Eurasia Social Sciences, Vol.: 7, Issue: 22, pp. (311-326).

i That study was presented verbally as a statement at USOBAK 2018 (International Research Congress on Social Sciences) and data relevant to the study were gathered in the course of $\mathrm{PhD}$ Dissertation practices by Sümeyra Ceyhan, which was carried out under the supervision of Assoc. Prof. Dr. Mustafa Yıldız. 